\title{
Towards the Stepwise Assembly of Molecular Borromean Rings. A Donor-Acceptor Ring-in-Ring Complex
}

\author{
Ross S. Forgan, Jason M. Spruell, John-Carl Olsen, Charlotte L. Stern and J. Fraser Stoddart* \\ Department of Chemistry, Northwestern University, 2145 Sheridan Road, Evanston, IL 60208, USA. Tel: +1-847-491-3793, \\ Fax:+1-847-491-1009, Email: stoddart@northwestern.edu, Web: http://stoddart.northwestern.edu
}

Dedicated to the Memory of Ernest L. Eliel

Received June 26, 2009; accepted September 10, 2009

\begin{abstract}
The assembly of molecular Borromean Rings from constitutionally independent rings in a stepwise manner depends on the preparation of robust "ring-in-ring" complexes. The $\pi$-electron rich macrocycle bis-1,5-dinaphtho[50]crown-14 (1) is shown to form a donor-acceptor ring-in-ring complex with the $\pi$-electron poor cyclophane cyclobis(paraquat-4,4'-biphenylene) $\left(2^{4+}\right)$ in solution. In the crystal superstructure of $[1 \subset 2] \cdot 4 \mathrm{PF}_{6}, \mathrm{CH} \cdots \mathrm{O}$ interactions between the polyether loops of $\mathbf{1}$ and the bipyridinium units of $\mathbf{2}^{\mathbf{4 +}}$ could disfavor the threading of dialkylammonium components of a third ring.

Keywords: Borromean Rings; Ring-in-Ring Complex; DonorAcceptor; Supramolecular Chemistry; Crystal Structure.
\end{abstract}

\section{Introduction}

Borromean Rings (BRs) are an assembly (Figure 1a and b) of three non-catenated rings in a Brunnian link, wherein scission of one ring leads to dissociation of the others [1]. Named after the Borromeo family of $15^{\text {th }}$ Century Milan who carried the topology on their family insignia [1], BRs have long been a source of inspiration and wonder to the human race, and,
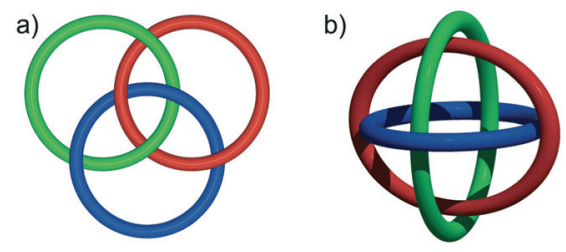

c)
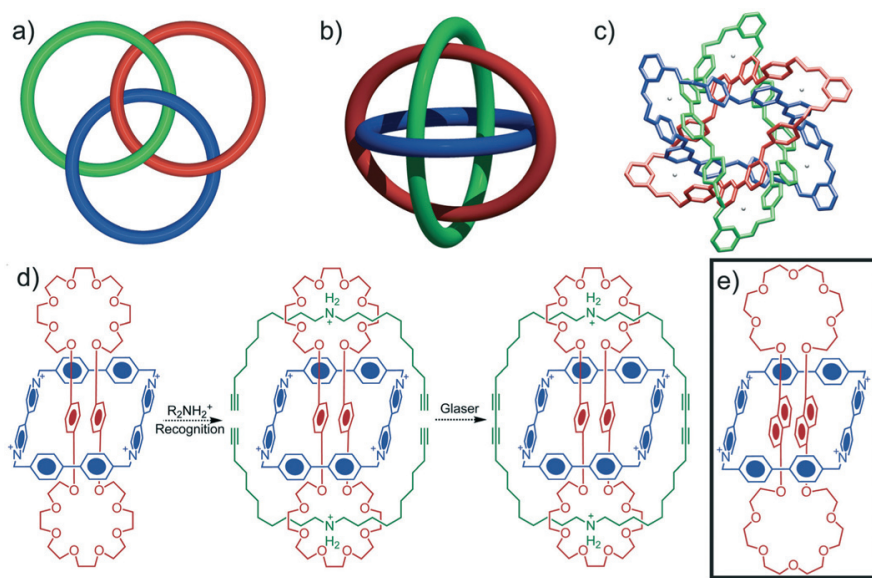

Fig. 1. a) BRs depicted as a Venn diagram. b) BRs depicted in three dimensions. c) Crystal structure of molecular BRs prepared by us [4]. d) Stepwise synthesis of BRs with constitutionally independent rings proposed by Busch [7]. e) The ring-in-ring complex expected to form between bis-1,5-dinaphtho[50]crown-14 (1) and cyclobis(paraquat$4,4^{\prime}$-biphenylene) $\left(2^{4+}\right)$ which is the basis for the research reported in this paper.
Resumen. El ensamblaje por pasos de Anillos Borromeos moleculares a partir de anillos constitucionalmente independientes depende de la preparación de complejos robustos "ring-in-ring". El macrociclo rico en electrones $\pi$ bis-1,5-dinafto[50]corona-14 (1) forma en solución un complejo "ring-in-ring" donador-aceptor con el ciclofano pobre en electrones $\pi$ ciclobis(paracuat-4,4'-bifenileno) $\left(2^{4+}\right)$. En la superestructura cristalina de $[\mathbf{1} \subset \mathbf{2}] \cdot 4 \mathrm{PF}_{6}$, las interacciones $\mathrm{CH} \cdots \mathrm{O}$ entre los lazos poliéteres de $\mathbf{1}$ y las unidades bipiridinio de $\mathbf{2}^{\mathbf{4 +}}$ pueden desfavorecer el enhebrado de componentes dialquilamonio de un tercer anillo.

Palabras clave: Anillos Borromeos; complejo "ring-in-ring"; donador-aceptor; Química Supramolecular; estructura cristalina.

in the last 20 years, particularly to the synthetic chemist [2]. BRs on the molecular scale were first realized by Seeman [3] in 1997, by elegant manipulation of DNA double helices. The twin powers of directionality and thermodynamic error checking, which are intrinsic to metal-templated dynamic covalent chemistry, were harnessed by us [4] in 2004 in the 18-component self-assembly of synthetic molecular BRs (Figure 1c). Borromean linkages have also been found in the solid-state structures of framework materials [5]. These "all-in-one" strategies have been the only successful routes to BRs to date, possibly because each of the three rings is identical, removing most selectivity issues between rings [6].

An arguably greater challenge is the stepwise assembly of BRs composed of three constitutionally different rings. This strategy has been termed the "ring-in-ring" approach [6], since the initial assembly requires that one macrocycle be threaded through another in an approximately perpendicular fashion. A potential "ring-in-ring" strategy (Figure 1d) was first proposed on paper by Busch [7], with the initial ring-in-ring complex to be formed by encircling two $\pi$-electron rich aromatic groups of a bis-paraphenylene crown ether with the established [8] $\pi$-electron deficient macrocycle cyclobis(paraquat-4,4'-biphenylene). Binding constrains each polyether loop of the crown to resemble smaller crown ethers, which have a well-known [9] propensity to bind dialkylammonium cations, to which could be appended threads with functionality capable of ringclosing to form BRs. We have shown subsequently that bis paraphenylene-[34]crown-10 associates with a macrocycle containing two dibenzylammonium moieties to give a ring-inring complex in both the solid and solution states [10]. Other ring-in-ring assemblies have been prepared [11] by transition 
metal templation, but no progress has been reported on the binding motif detailed in Figure 1d. On the basis of simple molecular modeling [12], bis-1,5-dinaphtho[50]crown-14 was selected [13] for study, since the dioxynaphthalene (DNP) aromatic rings are better $\pi$-electron donors than hydroquinone rings and the polyether chain length is expected to give a loop of similar size to dibenzo[24]crown-8. We report herein the assembly and characterization of the ring-in-ring complex (Figure 1e) formed between bis-1,5-dinaphtho[50]crown-14 (1) and cyclobis(paraquat-4,4'-biphenylene) tetrakis(hexafluor ophosphate) $\left(2 \cdot 4 \mathrm{PF}_{6}\right)$.

\section{Results and Discussion}

The crown ether 1 was prepared (see Scheme 1 and the Experimental Section) by a pseudo-high dilution macrocyclization of the ditosylate 3 [14] and 1,5-dioxynaphthalene in $30 \%$ yield. When one equivalent of $2 \cdot 4 \mathrm{PF}_{6}$ was added to a solution of 1 in $\mathrm{CD}_{3} \mathrm{CN}$ an immediate color change from light brown to intense purple was observed, which is characteristic of charge-transfer complex formation $\left(\lambda_{\max }=521 \mathrm{~nm}\right.$ by UV/ Vis spectroscopy). Significant changes were observed in the ${ }^{1} \mathrm{H}$ NMR spectrum (Figure 2) of $\mathbf{1}$ in the presence of $2 \cdot 4 \mathrm{PF}_{6}$.

The signals attributed to the aromatic protons of 1 all shift upfield, with the signal for the $\mathrm{H}_{4 / 8}$ protons moving by nearly $1.5 \mathrm{ppm}, \mathrm{H}_{3 / 7}$ by $0.67 \mathrm{ppm}$ and $\mathrm{H}_{2 / 6}$ by $0.5 \mathrm{ppm}$, presumably because of the shielding imposed by the proximity of the protons to the electron-deficient aromatic portions of $\mathbf{2}^{\mathbf{4}}$. The $O$-methylene resonances of $\mathbf{1}$ become more distinct upon complexation for each symmetry-independent $O$-methylene group of the hexaethylene glycol chain. There are also changes in the spectrum of $\mathbf{2}^{\mathbf{4}}$, with the $\beta$-proton resonances moving significantly upfield by $0.5 \mathrm{ppm}$. Small shifts are observed for all other signals.

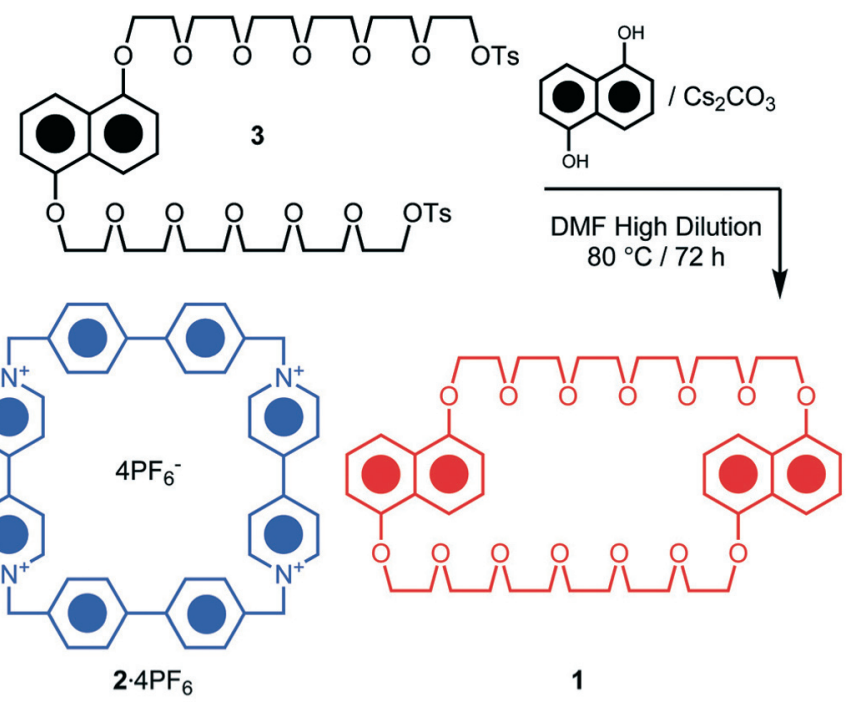

Scheme $\mathbf{1}$. The two rings $\mathbf{1}$ and $\mathbf{2} \cdot 4 \mathrm{PF}_{6}$ together with the last step in the synthesis of the crown ether 1 .
The dynamic solution behavior of the complex was examined by variable temperature ${ }^{1} \mathrm{H}$ NMR spectroscopy (Figure 3), with a $6.67 \mathrm{mM}$ solution in $\mathrm{CD}_{3} \mathrm{CN}$ cooled to $243 \mathrm{~K}$ and spectra recorded at $10 \mathrm{~K}$ intervals as the solution was heated to $333 \mathrm{~K}$. Exchange between bound and unbound species is fast on the ${ }^{1} \mathrm{H}$ NMR timescale, with only a single averaged resonance observed for each proton. The significant upfield shifts of the resonances for the aromatic protons of $\mathbf{1}$ at lower temperatures indicate that the complex is stabilized at lower temperature, an observation consistent with the fact that the color arising from the proposed charge transfer complex $[1 \subset 2] \cdot 4 \mathrm{PF}_{6}$ is significantly attenuated upon heating the mix-

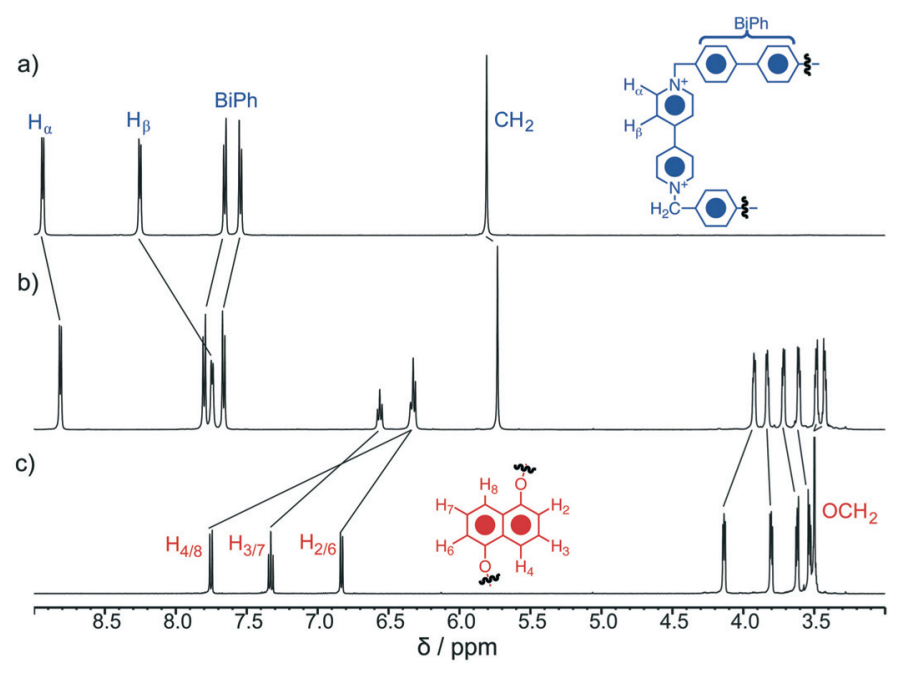

Fig. 2. ${ }^{1} \mathrm{H}$ NMR spectra (500 MHz, $6.67 \mathrm{mmol}$ in $\mathrm{CD}_{3} \mathrm{CN}, 293 \mathrm{~K}$ ) of a) cyclobis(paraquat-4,4'-biphenylene) tetrakis(hexafluorophosphate) $\left.\left(2 \cdot 4 \mathrm{PF}_{6}\right), \mathbf{b}\right)$ a $1: 1$ mixture of $\mathbf{1}$ and $2 \cdot 4 \mathrm{PF}_{6}$, and c) bis-1,5dioxynaphtho[50]crown-14 (1).

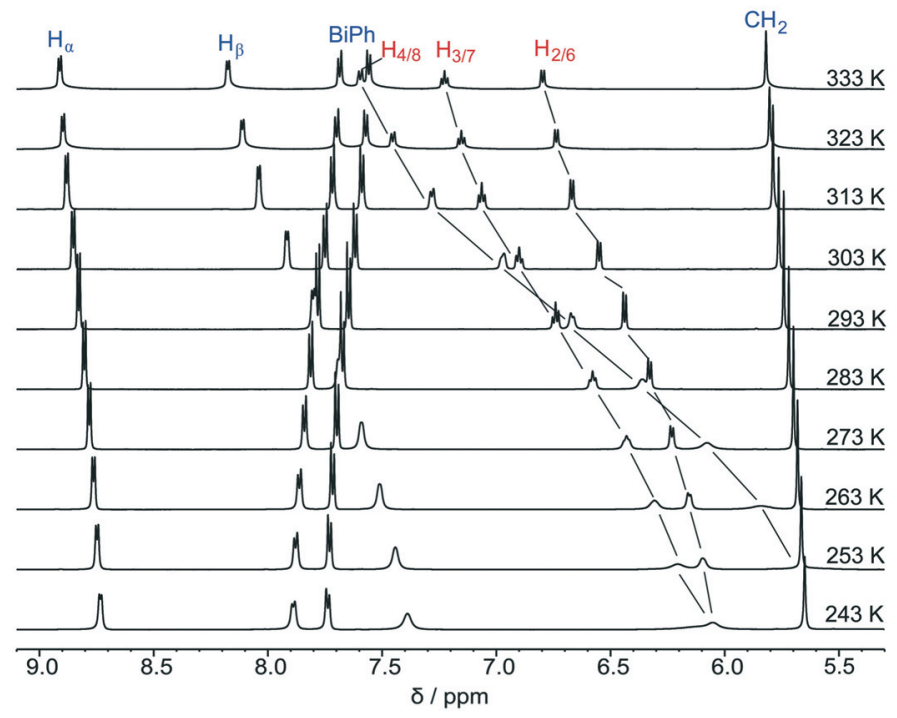

Fig. 3. Partial ${ }^{1} \mathrm{H}$ NMR spectra $\left(600 \mathrm{MHz}, 6.67 \mathrm{mmol}\right.$ in $\left.\mathrm{CD}_{3} \mathrm{CN}\right)$ of a $1: 1$ mixture of $\mathbf{1}$ and $2 \cdot 4 \mathrm{PF}_{6}$ recorded over a range of temperatures from $243 \mathrm{~K}$ up to $333 \mathrm{~K}$. 
ture of 1 and $2 \cdot 4 \mathrm{PF}_{6}$. The resonances at $243 \mathrm{~K}$ for $\mathrm{H}_{4 / 8}$ (broadened into baseline around $5.5 \mathrm{ppm}$ ), $\mathrm{H}_{3 / 7}$ (broad at $6.0 \mathrm{ppm}$ ) and $\mathrm{H}_{2 / 6}$ (broad at $6.1 \mathrm{ppm}$ ) are very similar to those observed [15] in the ${ }^{1} \mathrm{H}$ NMR spectrum at $333 \mathrm{~K}$ (in 7:3 $\mathrm{CD}_{3} \mathrm{COCD}_{3} /$ $\mathrm{CD}_{3} \mathrm{CN}$ ) of the related [3] catenane formed between $2^{4+}$ and two bis-1,5-dioxynaphtho[38]crown-10 molecules. At this temperature, free circumrotation of the crown ethers around $2^{4+}$ occurs in the [3]catenane, generating averaged signals for the encircled and alongside DNP protons. The fact that very similar averaged chemical shifts are observed in the mixture of $\mathbf{1}$ and $\mathbf{2}^{\mathbf{4 +}}$ at $243 \mathrm{~K}$ suggests that the DNP units are spending a considerable amount of their time encapsulated by the cyclophane, forming the expected $[1 \subset 2] \cdot 4 \mathrm{PF}_{6}$ complex (Figure 1e).

Attempts to characterize the assembly by mass spectrometry have so far been unsuccessful, further indicating the dynamic nature of the complex. Both ESI and MALDI were attempted, and peaks corresponding to $\mathbf{1}$ and $\mathbf{2}^{\mathbf{4 +}}$ were observed but not for $[\mathbf{1} \subset \mathbf{2}]$ in any ionization state. The high dilution of samples in ESI, coupled with the high temperatures required for ionization, is expected to disfavor complex formation, and softer ionization techniques are currently being examined.

Confirmation of the ring-in-ring complex assembly in the solid state came with the preparation, by vapor diffusion of $\mathrm{Et}_{2} \mathrm{O}$ into a $\mathbf{1 : 1}$ mixture of $\mathbf{1}$ and $\mathbf{2} \cdot 4 \mathrm{PF}_{6}$ in $\mathrm{MeNO}_{2}$, of blue, block-shaped single crystals suitable for analysis by X-ray diffraction, and the subsequent determination (Figure 4) of the crystal superstructure [16]. $[\mathbf{1} \subset \mathbf{2}] \cdot 4 \mathrm{PF}_{6}$ shows the expected binding motif, with two crystallographically independent complexes in the unit cell. In each, two DNP units are encapsulated (Figure 4) within the cyclophane in an acceptor-donor-donoracceptor $\pi$-stack (Figure 4e), with the polyether chains protruding above and below the cyclophane. The $\mathrm{H}_{4 / 8}$ protons of the DNP units are in close proximity to the cyclophane, enjoying an edge-to-face $\mathrm{CH}^{\cdots} \pi$ interaction (Figure $4 \mathrm{c}$ ), explaining the significant shifts seen in the ${ }^{1} \mathrm{H}$ NMR spectrum of the complex in solution. Furthermore, $\mathrm{CH} \cdots \mathrm{O}$ interactions between the polyether loops and the bipyridinium units of the cyclophane are prevalent (Figure 4a), causing the loops to fold down on to the rim of the cyclophane. Hydrogen bonds form between $\mathrm{H}_{\alpha}$ and the fourth oxygen along the chain, and between the $\mathrm{H}_{\beta}$ and the second oxygen along the chain. The cyclophane $2^{4+}$ distorts significantly by allowing the bipyridinium units to deviate from co-planarity ( $\theta$ in Figure 4 e) to accommodate the hydrogen bonds.

If the ring-in-ring complex is going to be utilized in the preparation of molecular BRs, removal of the $\mathrm{CH}^{\cdots} \mathrm{O}$ interactions will be necessary in order to allow binding of dialkylammonium centers in the polyether loops. This geometry represents a significant obstacle in the assembly of molecular BRs using this binding motif, as threading of the components of the third macrocycle will destabilize the interactions between the first two macrocycles, illustrating the efficiency and necessity of a wholly convergent stepwise synthetic route.

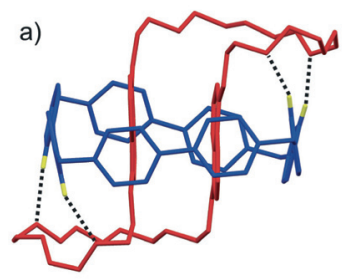

d)

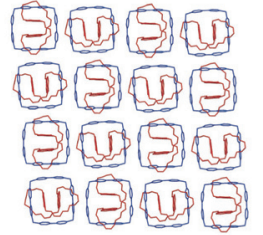

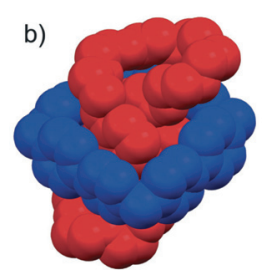

e)

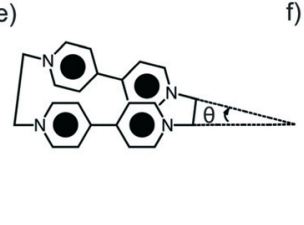

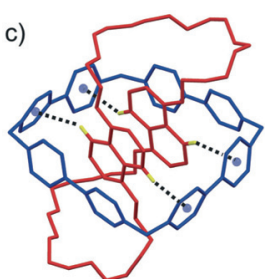

f)

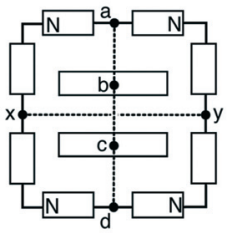

Fig. 4. All hydrogen atoms not involved in interactions and counterions have been removed for clarity, (multiple values are a result of the two symmetry independent supermolecules in the unit cell). a) One of the crystallographically independent complexes in the crystal superstructure of $[\mathbf{1} \subset \mathbf{2}] \cdot 4 \mathrm{PF}_{6}$ showing $\mathrm{CH} \cdots \mathrm{O}$ interactions. $\mathrm{CH}_{\alpha} \cdots \mathrm{O}, \mathrm{C} \cdots \mathrm{O}$ Distances and $\mathrm{CH}_{\alpha} \cdots \mathrm{O}$ angles: $2.22,3.13 \AA$ and $157.8^{\circ} ; 2.51,3.39 \AA$ and $154.8^{\circ} ; 2.55,3.45 \AA$ and $157.0^{\circ} ; 2.29,3.19 \AA$ and $156.8^{\circ} . \mathrm{CH}_{\beta} \cdots \mathrm{O}$, $\mathrm{C} \cdots \mathrm{O}$ Distances and $\mathrm{CH}_{\beta} \cdots \mathrm{O}$ angles: $2.29,3.21 \AA$ and $163.5^{\circ} ; 2.49$, $3.41 \AA$ and $162.3^{\circ} ; 2.37,3.26 \AA$ and $156.0^{\circ} ; 2.26,3.19 \AA$ and $165.1^{\circ}$. b) Space-filling representation of the same complex unit. c) $\mathrm{CH} \cdots \pi$ Interactions between $\mathrm{H}_{4 / 8}$ of 1 and the biphenylene units of $2^{4+} . \mathrm{CH}_{4 /}$ $8 \cdots \pi$ Distances, where $\pi$ is the centroid of the adjacent aromatic ring: $2.87,2.87,2.73,2.74,2.68,2.74,2.83$ and $2.93 \AA$. d) Packing diagram showing the chessboard arrangement of complex supermolecules. e) Schematic illustrating the distortion of $\mathbf{2}^{4+}: \theta=21.1,21.0,20.0,20.1^{\circ}$. f) $\pi-\pi$ Interactions in $[\mathbf{1} \subset \mathbf{2}] \cdot 4 \mathrm{PF}_{6}: \mathrm{a} \cdots \mathrm{b}=3.33,3.33 \AA ; \mathrm{b} \cdots \mathrm{c}=3.59,3.66$ $\AA ; \mathrm{c} \cdots \mathrm{d}=3.38,3.40 \AA ; \mathrm{a} \cdots \mathrm{d}=10.35,10.36 \AA ; \mathrm{x} \cdots \mathrm{y}=10.79,10.80 \AA$.

The long-range packing arrangement of $[\mathbf{1} \subset \mathbf{2}] \cdot 4 \mathrm{PF}_{6}$ is defined by $\pi-\pi$ stacking interactions between the aromatic groups of $\mathbf{2}^{\mathbf{4}}$. A bipyridinium unit of one molecule aligns in a slightly offset manner with a biphenyl moiety of another, with centroid-to-centroid distances (centroids placed at the centre of each bipyridinium or biphenyl 12-atom group) ranging from 3.69 to $3.74 \AA$. These interactions result in an infinite, two-dimensional, chessboard-like alignment of supermolecules (Figure $4 \mathrm{~d}$ ), which are oriented at $90^{\circ}$ to their nearest neighbours. These two-dimensional sheets stack on top of each other, with $\mathrm{PF}_{6}{ }^{-}$counterions filling the voids, to give the threedimensional packing superstructure.

\section{Conclusions}

In a nutshell, we have prepared and characterized a donoracceptor ring-in-ring complex from the $\pi$-electron rich macrocycle bis-1,5-dioxynaphtho[50]crown-14 (1) and the $\pi$-electron poor cyclophane cyclobis(paraquat-4,4'-biphenylene) $\left(\mathbf{2}^{\mathbf{4}^{+}}\right)$, with complex formation occurring via a motif first proposed in the literature 10 years ago [7]. Determination of the crystal superstructure, however, reveals $\mathrm{CH} \cdots \mathrm{O}$ interactions between the polyether loops of $\mathbf{1}$ and the bipyridinium units of $\mathbf{2}^{\mathbf{4}}$, a discovery that complicates the synthetic design of molecular BRs based on this ring-in-ring complex. If molecular BRs are 
to be obtained by this synthetic route, an elegant design maximizing supramolecular interactions will be necessary to compensate for the breaking of the thermodynamically favorable $\mathrm{CH} \cdots \mathrm{O}$ interactions.

\section{Experimental}

All chemicals and reagents were used as received from Sigma Aldrich. The tetracationic cyclophane $2 \cdot 4 \mathrm{PF}_{6}$ was prepared [8] according to previously published methods. The ditosylate precursor 3 was prepared as described by Ghosh et al. [14]. Nuclear magnetic resonance (NMR) spectra were recorded at $293 \mathrm{~K}$ unless otherwise noted on Bruker Avance 500 and 600 spectrometers, with working frequencies of 500 and $600 \mathrm{MHz}$ for ${ }^{1} \mathrm{H}$ and $125 \mathrm{MHz}$ for ${ }^{13} \mathrm{C}$. Chemical shifts are reported in ppm relative to signals corresponding to residual non-deuterated solvents. All ${ }^{13} \mathrm{C}$ experiments were performed with simultaneous decoupling of proton nuclei. UV/Vis spectra were obtained on a Perkin Elmer LAMBDA 1050 spectrometer. Electrospray ionisation (ESI) mass spectra were obtained on an Agilent 6210 LC-TOF high-resolution mass spectrometer. MALDI mass spectra were obtained on a Bruker Daltonics AutoFlex III MALDI-TOF mass spectrometer using 2,5-dihydroxybenzoic acid as matrix.

\section{Bis-1,5-Dioxynaphtho[50]crown-14 (1)}

1,5-Dioxynapthalene $(91.5 \mathrm{mg}, 0.571 \mathrm{mmol})$ and $3(569 \mathrm{mg}$, $0.571 \mathrm{mmol}$ ) were added dropwise over $24 \mathrm{~h}$ as a solution in dry DMF $(25 \mathrm{ml})$ to a heated $\left(80{ }^{\circ} \mathrm{C}\right)$ suspension of $\mathrm{Cs}_{2} \mathrm{CO}_{3}$ $(930 \mathrm{mg}, 2.86 \mathrm{mmol})$ in dry DMF $(50 \mathrm{ml})$ under $\mathrm{N}_{2}$ and the mixture was heated for a further $72 \mathrm{~h}$. The solvent was removed in vacuo, the residues dissolved in $\mathrm{CH}_{2} \mathrm{Cl}_{2}(100 \mathrm{ml})$ and washed with aqueous $\mathrm{NH}_{4} \mathrm{Cl}(1 \mathrm{M}, 100 \mathrm{ml})$ and $\mathrm{H}_{2} \mathrm{O}(2$ $\times 100 \mathrm{ml})$. The organic phase was dried $\left(\mathrm{Na}_{2} \mathrm{SO}_{4}\right)$ and the solvent removed in vacuo to yield a blueish tar, which was purified by flash chromatography $\left(\mathrm{SiO}_{2}: 10 \% \mathrm{MeOH} / \mathrm{EtOAc}\right)$ to yield 1 as a brown oil which gradually solidified (140 mg, $0.172 \mathrm{mmol}, 30 \%) .{ }^{1} \mathrm{H}$ NMR $\left(500 \mathrm{MHz}, \mathrm{CDCl}_{3}\right) \delta 7.82(4 \mathrm{H}$, $\left.\mathrm{d}, J=8.5 \mathrm{~Hz}, \mathrm{Ar}-H_{4 / 8}\right), 7.30\left(4 \mathrm{H}, \mathrm{t}, J=8.0 \mathrm{~Hz}, \mathrm{Ar}-H_{3 / 7}\right), 6.74$ $\left(4 \mathrm{H}, \mathrm{d}, J=7.7 \mathrm{~Hz}, \mathrm{Ar}-\mathrm{H}_{2 / 6}\right), 4.18\left(8 \mathrm{H}, \mathrm{t}, J=4.5 \mathrm{~Hz}, \mathrm{Ar}-\mathrm{OCH}_{2}\right)$, $3.90\left(8 \mathrm{H}, \mathrm{t}, J=4.5 \mathrm{~Hz}, \mathrm{Ar}-\mathrm{OCH}_{2} \mathrm{CH}_{2}\right), 3.72(8 \mathrm{H}, \mathrm{m}, \mathrm{Ar}-$ $\left.\mathrm{OC}_{2} \mathrm{H}_{4} \mathrm{OCH}_{2}\right), 3.64\left(8 \mathrm{H}, \mathrm{m}, \mathrm{Ar}-\mathrm{OC}_{2} \mathrm{H}_{4} \mathrm{OCH}_{2} \mathrm{CH}_{2}\right), 3.62(16 \mathrm{H}$, s, $\left.\mathrm{Ar}-\left(\mathrm{OC}_{2} \mathrm{H}_{4}\right)_{2} \mathrm{OC}_{2} H_{4}\right) ;{ }^{13} \mathrm{C} \mathrm{NMR}\left(125 \mathrm{MHz}, \mathrm{CDCl}_{3}\right) \delta 154.4$, 126.8, 125.2, 114.7, 105.7, 71.1, 70.8, 70.8, 70.8, 69.9, 68.0; ESI-HRMS (MeCN) $m / z$ 830.4329, calc for $\mathrm{C}_{44} \mathrm{H}_{60} \mathrm{O}_{14} \cdot \mathrm{NH}_{4}{ }^{+}$ $=830.4321$.

$[\mathbf{1} \subset \mathbf{2}] \cdot \mathbf{4} \mathbf{P F}_{\mathbf{6}} \cdot \mathbf{1}(4.1 \mathrm{mg}, 5 \mu \mathrm{mol})$ and $\mathbf{2} \cdot 4 \mathrm{PF}_{6}(6.2 \mathrm{mg}, 5 \mu \mathrm{mol})$ were dissolved in $\mathrm{CD}_{3} \mathrm{CN}(0.75 \mathrm{ml})$ to give a purple solution, and the solvent was removed in vacuo to yield a blue powder $(10.3 \mathrm{mg}, 100 \%)$. UV/Vis $\left(\mathrm{CD}_{3} \mathrm{CN}, 4 \mathrm{mM}\right) \lambda_{\max } 521 \mathrm{~nm}$. Single crystals of $[\mathbf{1} \subset \mathbf{2}] \cdot 4 \mathrm{PF}_{6}$ were prepared by slow vapor diffusion of $\mathrm{Et}_{2} \mathrm{O}$ into a $\mathrm{MeNO}_{2}$ solution. X-Ray diffraction data were collected at 100 (2) K with on a Bruker SMART APEX
II diffractometer fitted with a CCD area detector $\left(\mathrm{MoK}_{\alpha}, \lambda=\right.$ $0.71073 \AA$, graphite monochromator). The structure was solved by direct methods and expanded using Fourier techniques [17]. Non-hydrogen atoms were refined anisotropically. Hydrogen atoms were included in idealized positions, but not refined. The proposed model was refined with contributions from the solvate, $28 \mathrm{MeNO}_{2}$ molecules, which were removed from the diffraction data using the Bypass procedure in Platon [18]. The total potential solvent accessible void volume was 2606.8 $\AA^{3}$ and the electron count / cell $=898 . \mathrm{C}_{92} \mathrm{H}_{100} \mathrm{~F}_{24} \mathrm{~N}_{4} \mathrm{O}_{14} \mathrm{P}_{4}$, $M_{\mathrm{r}}=2065.64$, triclinic, space group, $P-1, a=18.7969(10) b$ $=21.3322$ (11) $c=29.2218$ (15) $\AA, \alpha=69.696$ (3) $\beta=84.942$ (4) $\gamma=89.939$ (4) ${ }^{\circ}, V=10941.0$ (10) $\AA^{3}, Z=4, T=100$ (2) $\mathrm{K}, 66287$ reflections collected, 9757 independent reflections $[R($ int $)=0.1949], R=0.0814, w R_{2}=0.1831, \operatorname{CCDC} 736589$.

\section{Acknowledgements}

JMS gratefully acknowledges the National Science Foundation for a Graduate Research Fellowship and Northwestern University for a Presidential Fellowship. The authors wish to thank Dr Jennifer Seymour of the Northwestern Analytical Services Laboratory for her continued time and assistance with all aspects of mass spectrometry.

\section{References}

1. Cromwell, P. R.; Beltrami E.; Rampichini, M. Math. Intelligencer 1998, 20 (1), 53-62.

2. a) Liang, C.; Mislow, K. J. Math. Chem. 1994, 16, 27-35. b) Mislow, K. Top. Stereochem. 1999, 22, 1-82.

3. Mao, C.; Sun, W.; Seeman, N. C. Nature 1997, 386, 137-138.

4. Chichak, K. S.; Cantrill, S. J.; Pease, A. R.; Chiu, S.-H.; Cave, G. W. V.; Atwood, J. L.; Stoddart, J. F. Science 2004, 304, 13081312.

5. For an examination of previously unnoticed BR topologies in framework materials see: a) Carlucci, L.; Ciani, G.; Proserpio, D. M. CrystEngComm 2003, 5, 269-279. For further examples see: b) Dobrzañska, L.; Raubenheimer, H. G; Barbour, L. J. Chem. Commun. 2005, 5050-5052. c) Liantonio, R.; Metrangolo, P.; Meyer, F.; Pilati, T.; Navarrini, W.; Resnati, G. Chem. Commun. 2006, 1819-1821. d) Lü, X.-Q.; Pan, M.; He, J.-R.; Cai Y.-P.; Kang, B.-S.; Su, C.-Y. CrystEngComm 2006, 8, 827-829. e) Li, J.; Song, L.; Du, S. Inorg. Chem. Commun. 2007, 10, 358 -361. f) Zhang, X.-L.; Guo, C -P.; Yang, Q.-Y.; Wang, W.; Liu W.-S.; Kang, B.- S.; Su, C.-Y. Chem. Commun. 2007, 4242-4244. g) Zhang, X.-L.; Guo, C.-P.; Yang, Q.-Y.; Lu, T.-B.; Tong, Y.-X.; Su, C.-Y. Chem. Mater. 2007, 19, 4630-4632. h) Yang, Q.-Y.; Zheng, S.-R.; Yang, R.; Pan, M.; Cao, R.; Su, C.-Y. CrystEngComm, 2008, 11, 680-685. i) Byrne, P.; Lloyd, G. O.; Clarke, N.; Steed, J. W. Angew. Chem., Int. Ed. 2008, 47, 57615764. j) Jang, J.-J.; Li, L.; Yang, T.; Kuang, D.-B.; Wang, W. Su, C.-Y. Chem. Commun. 2009, 2387-2389. k) Men, Y.-B.; Sun, J.; Huang, Z.-T.; Zheng, Q.-Y. Angew. Chem., Int. Ed. 2009, 48, 2873-2876.

6. Cantrill, S. J.; Chichak, K. S.; Peters, A. J.; Stoddart, J. F. Acc. Chem. Res. 2005, 38, 1-9.

7. Hubin, T. J.; Kolchinski, A. G.; Vance, A. L.; Busch, D. H. Adv. Supramol. Chem. 1999, 5, 237-357. 
8. Asakawa, M.; Ashton, P. R.; Menzer, S.; Raymo, F. M.; Stoddart, J. F.; White, A. J. P.; Williams, D. J. Chem. Eur. J. 1996, 2, 877893.

9. Ashton, P. R.; Campbell, P. J.; Chrystal, E. J. T.; Glink, P. T.; Menzer, S.; Philp, D.; Spencer, N.; Stoddart, J. F.; Tasker, P. A.; Williams, D. J. Angew. Chem., Int. Ed. Engl. 1995, 34, 18651869.

10. Chiu, S.-H.; Pease, A. R.; Stoddart, J. F.; White, A. J. P.; Williams, D. J. Angew. Chem., Int. Ed. 2002, 41, 270-274.

11. a) Schmittel, M.; Ganz, A.; Fenske, D. Org. Lett. 2002, 4, 2289 2292. b) Loren, J. C.; Yoshizawa, M.; Haldimann, R. F.; Linden, A.; Siegel, J. S. Angew. Chem., Int. Ed. 2003, 42, 5702-5705. c) Liu, Y. Tet. Lett. 2007, 48, 3871-3874.

12. Calculations were carried out using Schrödinger MacroModel v9.6. A structural model of $[\mathbf{1} \subset \mathbf{2}] \cdot 4 \mathrm{Cl}$ was built based on a related crystal structure of a [5]catenane [13] which has two dioxynaphthalene units encompassed by $\mathbf{2}^{4+}$. A conformational search using OPLS carried out in water showed that the polyether loops were of appropriate size to bind a dialkylammonium cation.

13. Amabilino, D. B.; Ashton, P. R.; Balzani, V.; Boyd, S. E.; Credi, A.; Lee, J. Y.; Menzer, S.; Stoddart, J. F.; Venturi, M.; Williams, D. J. J. Am. Chem. Soc. 1998, 120, 4295-4307.
14. Ghosh, S.; Ramakrishnan, S. Angew. Chem., Int. Ed. 2004, 43, 3264-3268.

15. Ashton, P. R.; Brown, C. L.; Chrystal, E. J. T.; Goodnow, T. T.; Kaifer, A. E.; Parry, K. P.; Slawin, A. M. Z.; Spencer, N.; Stoddart, J. F.; Williams, D. J. Angew. Chem., Int. Ed. Engl. 1991, 30, 1039-1042.

16. CCDC 736589 contains the supplementary crystallographic data for this paper. These data can be obtained free of charge via www. ccdc.cam.ac.uk/data_request/cif, or by emailing data_request@, ccdc.cam.ac.uk, or by contacting The Cambridge Crystallographic Data Centre, 12, Union Road, Cambridge CB2 1EZ, UK; fax: +44 1223336033.

17. Sheldrick, G. M. SHELXTL Version 6.14. Program for Solution and Crystal Structure Refinement, University of Göttingen, Göttingen, Germany, 1997.

18. Van der Sluis, P.; Spek, A. L. BYPASS. An Effective Method for the Refinement of Crystal Structures Containing Disordered Solvent Regions. Acta Cryst. A46, 194-201. 